\title{
Assessing the Availability of Rice by Using System Dynamics Approach in West Java, Indonesia
}

\author{
Maun Jamaludin ${ }^{1, *}$, Teddy Hikmat Fauzi ${ }^{1}$, Yuyun Yuniarti ${ }^{1}$, Mulyaningsih ${ }^{2}$ \\ ${ }^{1}$ Department of Business Administration, Faculty of Social and Political Sciences, Pasundan University, \\ Bandung, West Java, Indonesia \\ ${ }^{2}$ Department of Public Administration, Graduate Faculty, Garut University, West Java, Indonesia
}

Received June 23, 2021; Revised August 16, 2021; Accepted September 8, 2021

\section{Cite This Paper in the following Citation Styles}

(a): [1] Maun Jamaludin, Teddy Hikmat Fauzi, Yuyun Yuniarti, Mulyaningsih, "Assessing the Availability of Rice by Using System Dynamics Approach in West Java, Indonesia," Universal Journal of Agricultural Research, Vol. 9, No. 5, pp. 156 - 165, 2021. DOI: 10.13189/ujar.2021.090502.

(b): Maun Jamaludin, Teddy Hikmat Fauzi, Yuyun Yuniarti, Mulyaningsih (2021). Assessing the Availability of Rice by Using System Dynamics Approach in West Java, Indonesia. Universal Journal of Agricultural Research, 9(5), 156 - 165. DOI: 10.13189/ujar.2021.090502.

Copyright $\bigcirc 2021$ by authors, all rights reserved. Authors agree that this article remains permanently open access under the terms of the Creative Commons Attribution License 4.0 International License

\begin{abstract}
This study aims to determine the dynamics of the rice availability system in West Java in terms of production and consumption, to obtain important variables that become the leverage point for determining rice availability. This study uses a case study method using the "System Dynamics" approach by using a database of actual production and population from 2014 to 2015 , and using it as an estimate of rice availability until 2025 . By using actual data of the annual average growth between 2014 and 2019 amounted to $2.81 \%$ for rice production, and of $1.12 \%$ for the population, the estimated rice availability is projected until 2025. Specifically, the analysis of Causal Loop Diagrams (CLD) and Stock and Flow Diagrams (SFD) shows that productivity and availability of paddy fields are two important variables that can provide a significant influence on the rice production system as a whole. The findings underscore the importance of productivity and land area as the basis for the study of developing a policy model to ensure the availability of rice in West Java. Theoretically, the findings can be used as a conceptual basis for projecting sustainable rice availability in an area. The results of this study practically have implications for the need to increase productivity and governance of agriculture and rice trade as a policy basis to ensure the availability of rice in West Java.
\end{abstract}

Keywords Rice Availability, Food Security, System Dynamics

\section{Introduction}

Food is a basic human need that must be met in sustaining life and living. Law No. 18 of 2012 concerning Food states that the state is obliged to realize the availability, affordability, and fulfillment of adequate, safe, quality and nutritionally balanced food consumption, both at the national and regional levels to individuals evenly throughout Indonesia all the time by utilizing local resources, institutions and culture. History has proven that the food problem is closely related to social security, economic stability, political stability and security or national security as a whole. Weaknesses in realizing food security will shake the joints of national security. Therefore, the development of a solid national food security system is an absolute requirement for national development. In Indonesia, the problem of food and food security cannot be separated from rice commodities, bearing in mind that rice is a staple food consumed by most of the people of Indonesia. This can be seen from the high participation of rice consumption which is more than $100 \%(97,7 \%)$, which means that almost all Indonesian households consume rice [1, 2, 3, 4].

The problem in realizing rice availability is related to the growth of rice demand which is faster than the growth of its supply $[5,6,7,8]$. The demand for rice increases in line with population growth, economic growth, people's purchasing power, and changes in tastes $[9,10,11]$. This demand-side dynamics causes the national demand for 
rice to increase in quantity, quality and diversity $[12,13$, $14,15]$. Meanwhile, the national rice production capacity is slowing down or can be said to be stagnant. If this problem cannot be overcome, the need for rice imports will increase, which if continued can result in a high dependency on imported rice, thus draining the country's foreign exchange $[10,13,15,16]$.

Research related to rice availability has been carried out in recent years $[17,18,19,20]$ state that food availability includes food quality, entity integrity, security and health, sustainable production, product diversification, and information services related to foodstuffs. The availability of food in the form of fresh products is also widely discussed [21, 22]. This study will continue to grow in line with the need for staple food which continues to increase every year. For this reason, a comprehensive and in-depth study is needed to guarantee the availability of staple food in Indonesia.

Appropriate design of a dynamic (changing with time) problem including the system of rice availability in food security can be done by using a system dynamics methodology [23]. System dynamics is an approach that uses perspectives based on information feedback and delay to understand the complex behavior dynamics of physical systems, biological systems and social systems [24, 25]. In addition, system dynamics is one of the modeling approaches based on system thinking and the principle of forming dynamic models [23]. The main assumption in the system dynamics paradigm is the structure of the phenomenon of the decision-making process is a collection (assembly) of causal structures that are circular and closed (causal loop structure) [26].

The demand for rice increases in line with population growth, economic growth, people's purchasing power, and changes in tastes. This demand-side dynamics causes the national demand for rice to increase in quantity, quality and diversity. West Java is one of the largest producers of rice in Indonesia, and with its large population amounted to nearly 50 million people, the availability and distribution of rice as the main staple food in Indonesia should be ensured [27, 28, 29].

This study aims to determine the dynamics of the system of rice availability in West Java viewed from the production and consumption sectors, to find a picture of the development of rice production and consumption in West Java, to get important variables that act as leverage points that can be used as basic variables the development of a sustainable rice availability policy model within the framework of guaranteeing the availability of rice in an area. West Java was chosen as the object of this study based on several considerations. First, rice is the main source of nutrition and energy (staples) of the majority of the population of West Java with the demand and consumption of rice tending to increase in line with increasing population and people's purchasing power [30]. Second, rice is a strategic commodity because it involves the source of income and household employment opportunities of millions of farmers in rural areas. Third, in term of location, West Java has a strategic role as one of the largest rice contributors (18\% or 6.24 million tons per year) in Indonesia and West Java producing the highest quality rice, such as: Cianjur, Sumedang, Setra and Jembar rice.

\section{Research Methods}

This research uses a case study method that aims to understand the phenomena and problems in the rice availability system in West Java in depth. This research was conducted using the "System Dynamics" approach which uses perspectives based on information feedback and delays to understand the complex behavioral dynamics of physical systems, biological systems and social systems [31]. The main data used were the actual production of Rice in West Java, 2014-2019 (Table 1). The main assumption in the "System Dynamics" approach is the structure of the phenomenon of the decision-making process which is a collection (assembly) of causal structures that are circular and closed [23]. This approach has been carried out to illustrate the rice availability system, including in projecting rice availability in Merauke studying behavior and relationships in the supply chain structure of perishable food $[13,15]$.

Table 1. Actual production and population of Rice in West Java, 2014-2019

\begin{tabular}{ccccccc}
\hline Production & $\mathbf{2 0 1 4}$ & $\mathbf{2 0 1 5}$ & $\mathbf{2 0 1 6}$ & $\mathbf{2 0 1 7}$ & $\mathbf{2 0 1 8}$ & $\mathbf{2 0 1 9}$ \\
\hline Actual & $11,644,899$ & $11,373,144$ & $12,540,550$ & $12,299,701$ & $12,494,919$ & $12,632,363$ \\
\hline Population & $\mathbf{2 0 1 4}$ & $\mathbf{2 0 1 5}$ & $\mathbf{2 0 1 6}$ & $\mathbf{2 0 1 7}$ & $\mathbf{2 0 1 8}$ & $\mathbf{2 0 1 9}$ \\
\hline Actual & $45,446,243$ & $46,073,401$ & $46,709,214$ & $47,353,801$ & $48,007,284$ & $48,669,784$ \\
\hline
\end{tabular}


Some studies examined the availability of rice in a pre-harvest perspective with a dry land-based simulation approach [32]. This research was conducted in 5 stages. The first stage is identifying the system, which is understanding the system correctly in the field, formulating and defining the problem so that it is representative, not biased, and does not deviate from the purpose of the analysis. Continued in the second stage is the conceptualization of the system, which is the preparation of a causal diagram based on the configuration of the availability of rice that has been obtained. The compilation of cause-and-effect diagrams aims to illustrate the interaction between elements in the rice supply system. This interaction has the possibility of positive or negative interactions. The relationship can be positive if an addition to one variable will cause an addition to another variable. However, if the addition of one variable will cause a reduction in another variable, then it can be said that the relationship between the two variables is negative. The third stage is the formulation of the model, the formulation of this model is done by describing stock and flow diagrams and composing mathematical formulations in the diagram. Stock and flow diagrams are models that are then simulated after mathematical formulation. The fourth step is model validation. Model validation is a step to ascertain whether the model made is in accordance with the perception of the model maker by checking the model on the Vensim PLE 64 software. In addition to checking the model, the validation process is also carried out by checking the unit or variable units contained in the model by doing a unit check on the model Vensim PLE 64 software. Model validation is also a step to see whether the model is able to describe the real system correctly.

The model is said to be valid, if the average of the two does not show a statistically significant difference. After the dynamics model of the rice availability system is said to be verified and valid, it is continued with a simulation model that has been developed using the Vensim PLE 64 software.

The model validation used in this study uses (3) three approaches namely, historical fit test, extreme condition test, and sensitivity analysis. Model validation using the historical suitability test method is done by comparing the actual conditions and the results of model-based simulations that have been developed. The model is declared valid when the deviation is less than $10 \%$, besides that the model validation also uses the calculation of the mean absolute percentage error (MAPE), which is mathematically written in the formula:

$$
M A P E=\left(\frac{100}{n}\right) \sum_{t=1}^{n}\left(\frac{\left|D_{t}-F_{t}\right|}{D_{t}}\right)
$$

Information: $\mathrm{Dt}$ is data in period $\mathrm{t}$ and $\mathrm{Ft}$ is forecast in period t.

Furthermore, extreme condition tests are carried out to ensure that the model developed does not provide irrational behavior. This test is carried out by giving the highest and lowest extreme values to the variable drivers which are then seen as rational or irrational.

The last stage carried out in this study is a simulation model. This model simulation is done with the aim to see the behavior of the rice supply system model that has been made, by entering the values in constants and function tables in accordance with the conditions contained in the real system. The final result of this study is to obtain several sensitive variables that are able to have a large impact on the rice supply system. It is the variable with a high level of sensitivity that will then be the basis for developing a sustainable rice supply policy model.

\section{Results}

The first step in making a system dynamics model is to identify a system that aims to provide an overview of the system. The model was created with the aim of studying the behavior of the system through detailed analysis on the components or elements in compiling the system and its interactions with one another. There are two main objectives in making a model of rice availability with a system dynamics approach, namely to obtain a picture of the cause-effect relationships in a system and to provide qualitative and quantitative interpretations of the system, and more to the level of application oriented on the problem namely to get a better prediction of the behavior of the system used as soon as possible if there are improvements, in the management of the system.

The second step is the conceptualization of the system, which is to study the interrelationship between the components of the system with the aim of directing the formation of qualitative models in the form of cause-effect diagrams. Causal loop diagrams show interactions between all interrelated elements/components (Figure 1). The rice availability model in West Java has two main loops, namely the loop reinforcement in rice production and the loop balancing in the business activities of shipping rice into and out of West Java. The availability of rice is positively influenced by rice production and the level of rice consumption, and negatively affected by rice trade outside the West Java region. Rice production in general is positively influenced by rice field area and land productivity. The availability of land turned out to be very limited, this was due to the high rate of conversion of agricultural land to non-agricultural land. An increase in population continues to increase every year resulting in increased demand for rice. 


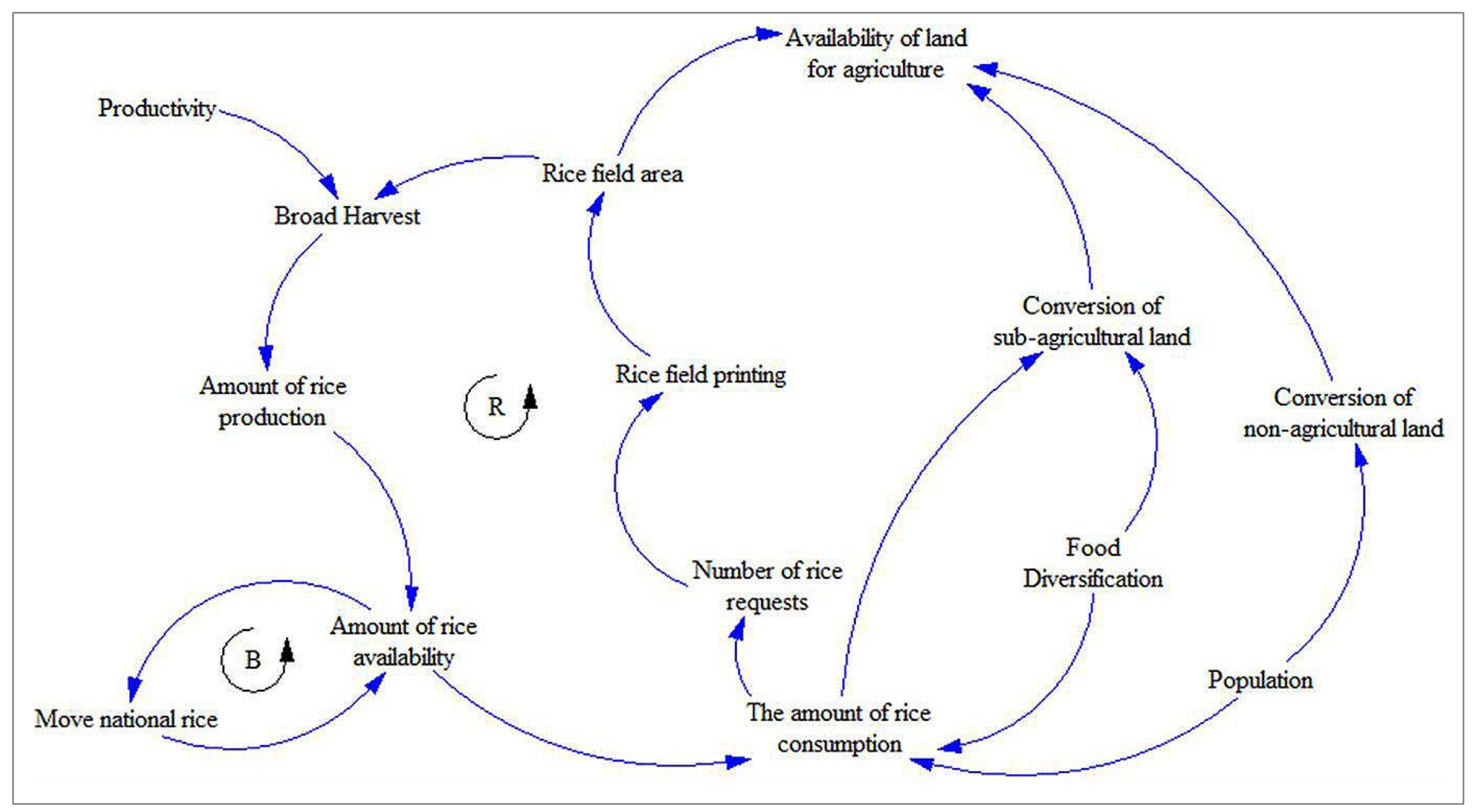

Figure 1. Causal Loop Diagram (CLD) of rice availability in West Java. 


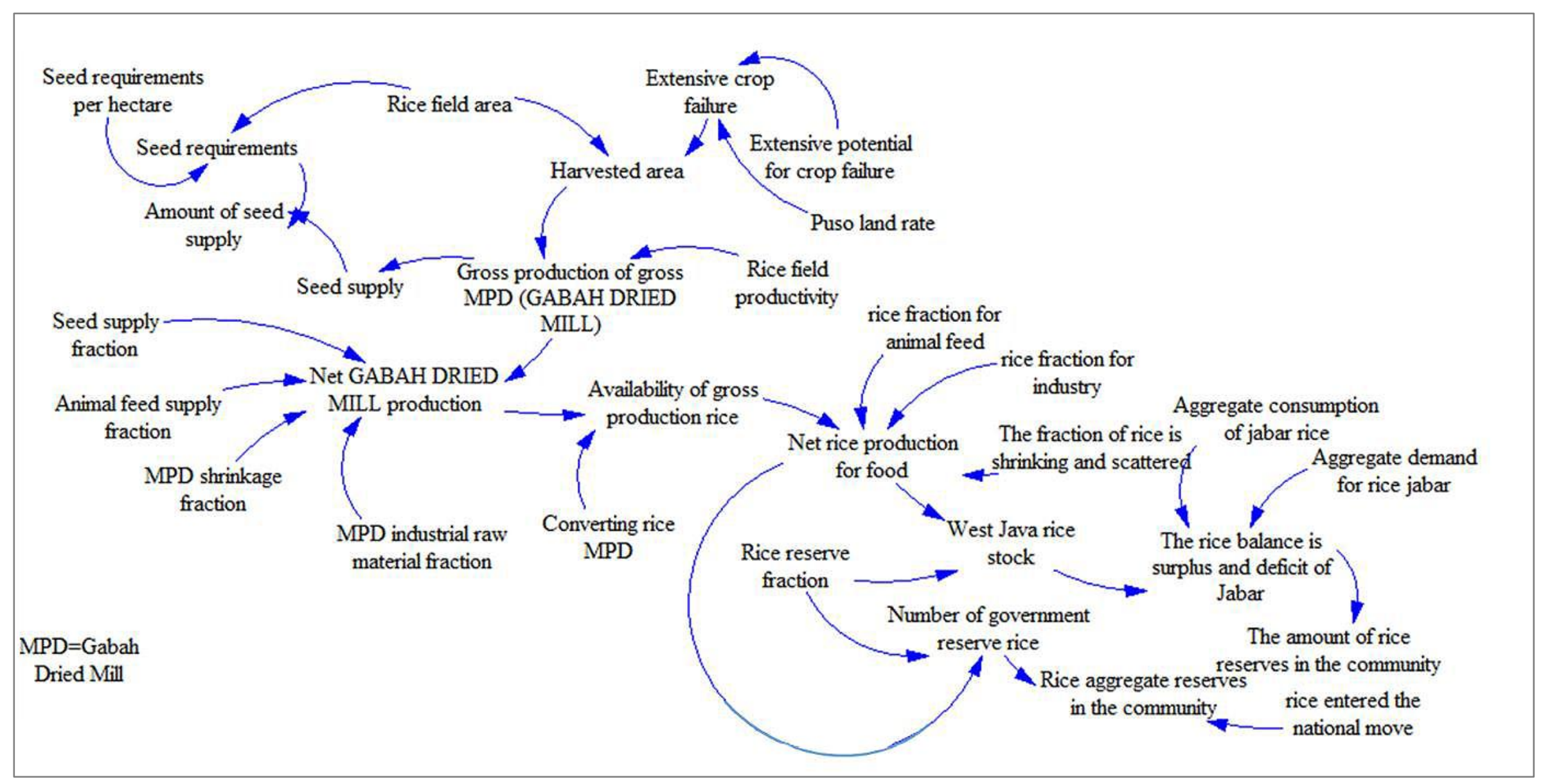




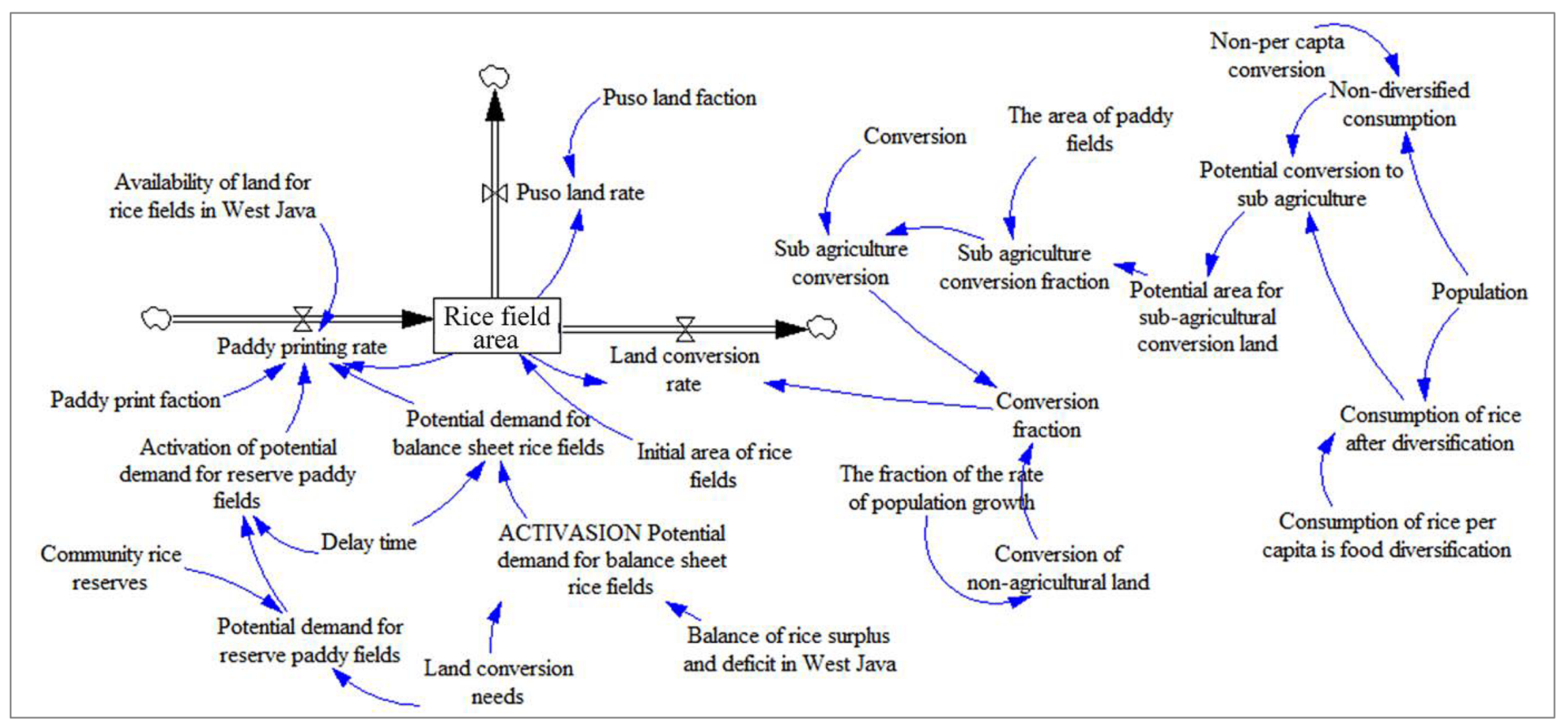

Figure 2. Stock and Flow Diagram (SFD) model of rice production in West Java 
The next step (the third step) after making a causal model (Causal Loop Diagram/CLD) of the availability of rice is to make a model/model structure formulation. This step is done by changing the cause-effect diagram (causal loop diagram) into Stock and Flow Diagrams (SFD) so that it can be understood by the computer software that will be used so that it can find out the dynamics behavior of the system caused by the assumptions of the model will be simulated (Figure 2).

The fourth step is the model validation test. Model validation test aims to determine its suitability with real systems in the field. In this research, the method used in the validation of this model is the historical behavior suitability test approach on two important variables (Milled GGG production and population) which shows that the standard deviation of the simulation results compared to the actual condition is not more than $10 \%$. Based on the results obtained it can be stated that the model developed is valid. The simulation results can be presented in Table 2 and graphically presented in Figure 3.

Table 2. Standard Deviation of the Rice Availability Model in West Java

\begin{tabular}{|c|c|c|c|c|c|c|}
\hline Production & 2014 & 2015 & 2016 & 2017 & 2018 & 2019 \\
\hline Actual & $11,644,899$ & $11,373,144$ & $12,540,550$ & $12,299,701$ & $12,494,919$ & $12,632,363$ \\
\hline Simulation & $12,774,454$ & $12,339,861$ & $13,166,323$ & $12,828,588$ & $11,557,800$ & $12,720,790$ \\
\hline $2.81 \%(2014-2025)$ & $9.70 \%$ & $8.50 \%$ & $4.99 \%$ & $4.30 \%$ & $-7.50 \%$ & $0.70 \%$ \\
\hline Population & 2014 & 2015 & 2016 & 2017 & 2018 & 2019 \\
\hline Actual & $45,446,243$ & $46,073,401$ & $46,709,214$ & $47,353,801$ & $48,007,284$ & $48,669,784$ \\
\hline Simulation & $46,286,998$ & $46,441,988$ & $46,900,722$ & $47,827,339$ & $48,400,943$ & $49,107,812$ \\
\hline $1.12 \%(2014-2025)$ & $9.70 \%$ & $8.50 \%$ & $4.99 \%$ & $4.30 \%$ & $-7.50 \%$ & $0.70 \%$ \\
\hline Production & 2020 & 2021 & 2022 & 2023 & 2024 & 2025 \\
\hline Actual & $12,771,319$ & $12,911,804$ & $13,053,883$ & $13,197,426$ & $13,342,597$ & $13,489,366$ \\
\hline Simulation & $13,205,544$ & $13,234,599$ & $12,753,595$ & $13,619,743$ & $13,809,588$ & $13,853,579$ \\
\hline $2.81 \%(2014-2025)$ & $3.40 \%$ & $2.50 \%$ & $-2.30 \%$ & $3.20 \%$ & $3.50 \%$ & $2.70 \%$ \\
\hline Population & 2020 & 2021 & 2022 & 2023 & 2024 & 2025 \\
\hline Actual & $49,341,427$ & $50,022,339$ & $50,712,647$ & $51,412,482$ & $52,121,974$ & $52,841,257$ \\
\hline Simulation & $49,755,895$ & $50,802,687$ & $51,311,056$ & $52,183,669$ & $52,820,408$ & $53,475,352$ \\
\hline $1.12 \%(2014-2025)$ & $0.84 \%$ & $1.56 \%$ & $1.18 \%$ & $1.50 \%$ & $1.34 \%$ & $1.20 \%$ \\
\hline
\end{tabular}

Source: Primary data processing, 2019

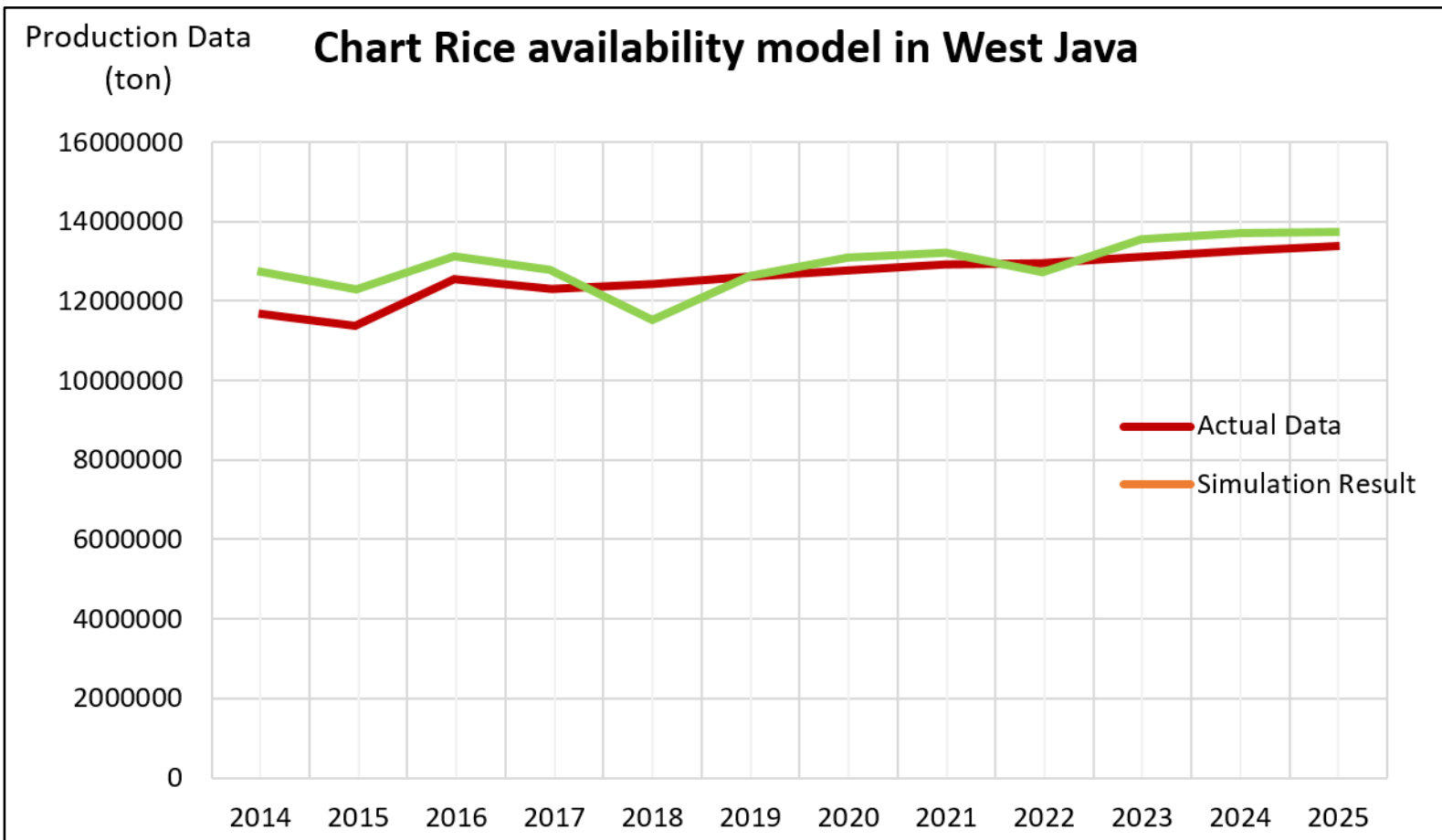




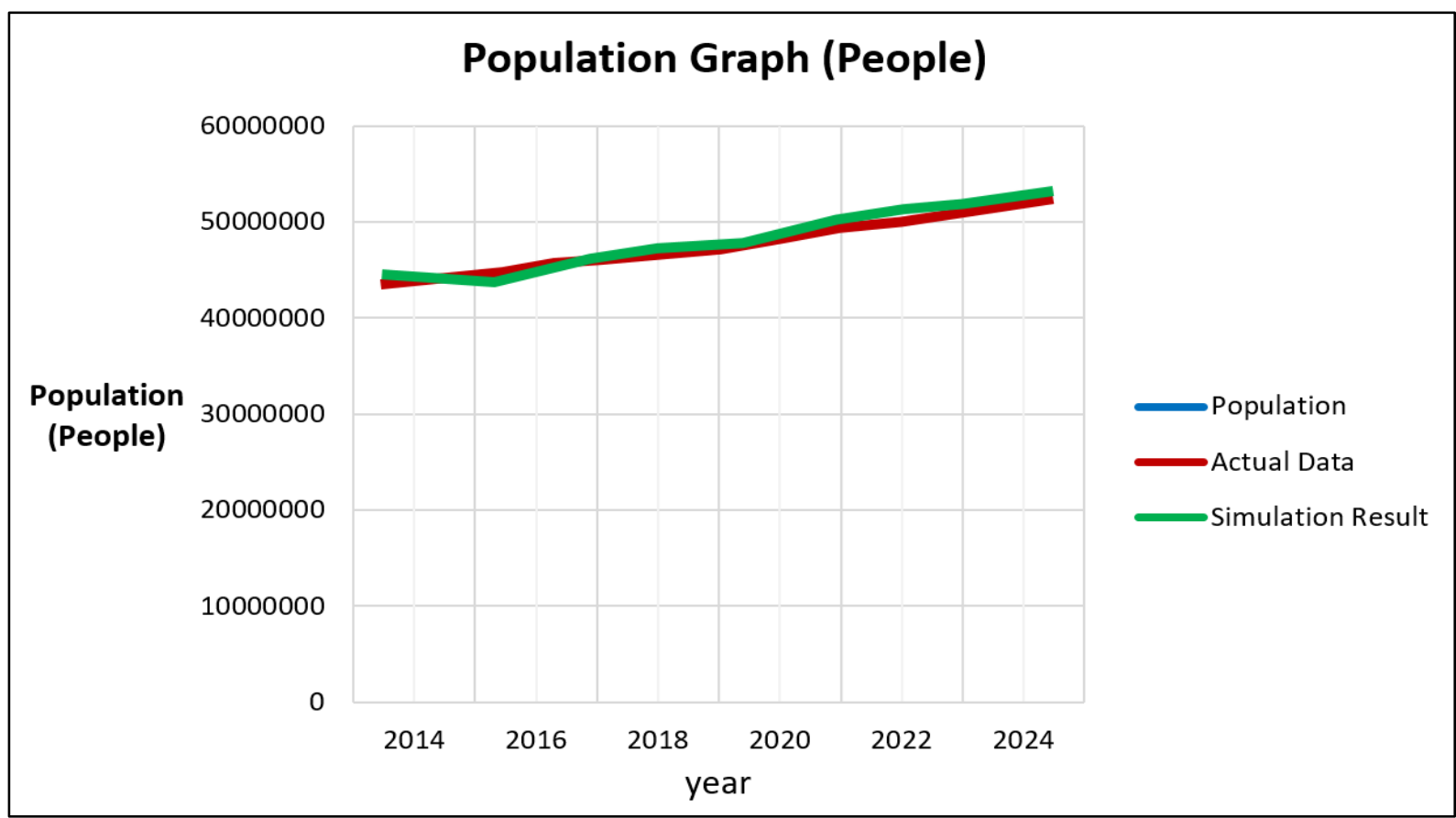

Figure 3. Historical compatibility test

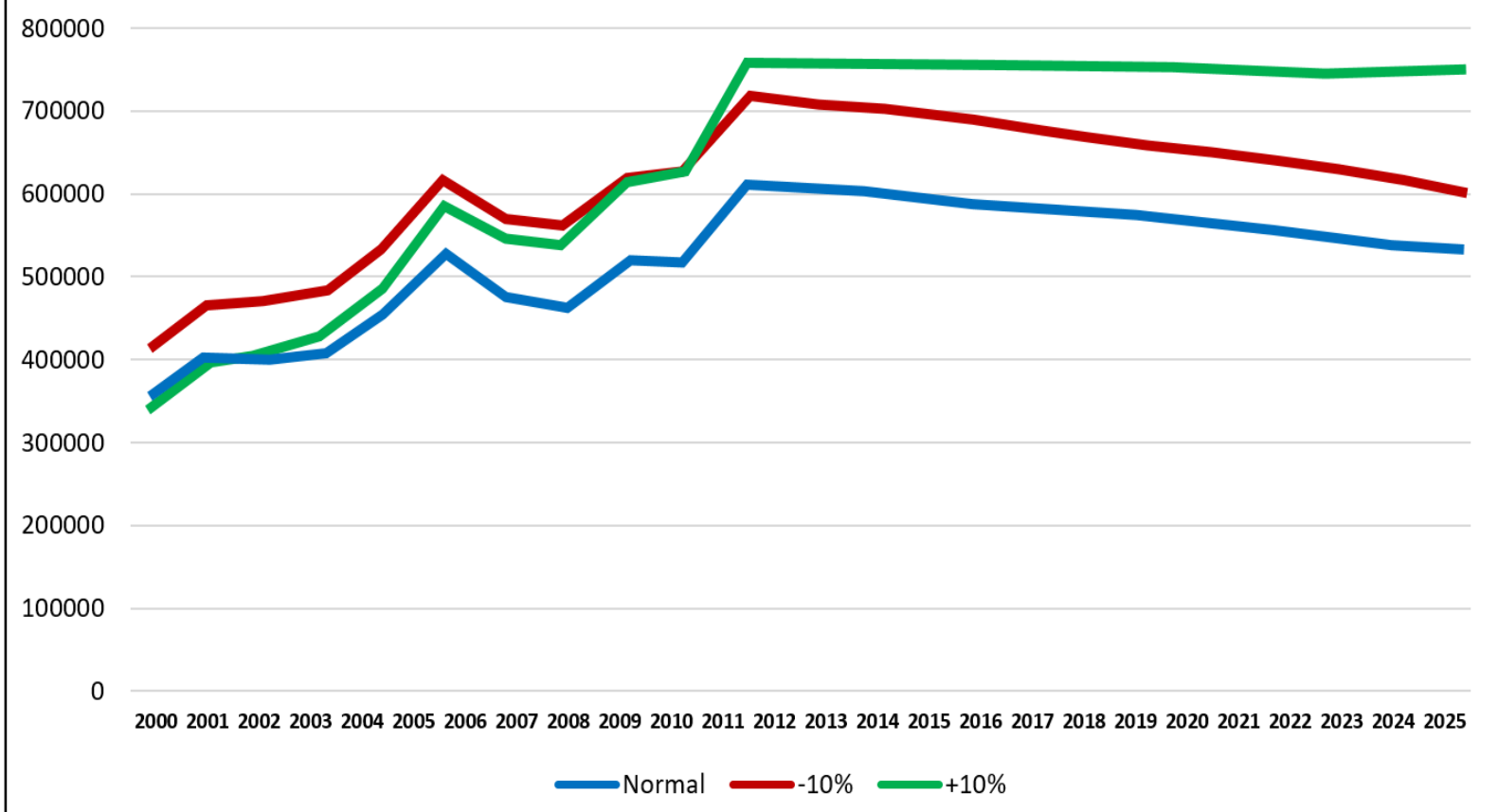

Figure 4. Sensitivity Test of Rice Consumption on Rice Balance

After the dynamics of the rice availability system model is said to be valid, the fifth stage is the simulation model. This simulation is carried out with the aim to see the behavior of the rice supply system model that has been made, by entering the values in constants and function tables in accordance with real system conditions in the field. Furthermore, the simulation also aims to project the availability of rice in West Java in 2019-2025, based on the current food security policy and rice system in West Java (Figure 3).
The final result of this study is sensitivity analysis. Sensitivity analysis is performed to determine the level of sensitivity/sensitivity of a variable affecting other variables. In this study, the tested variable is an exogenous variable (independent variable), which is to test whether the exogenous variable gives the same response/influence on the actual conditions. In this study, the variable to be tested for sensitivity is the variable consumption of rice per capita and productivity which is assessed to have an impact on the rice balance and deficit balance in West 
Java. With changes in consumption increasing by $10 \%$ giving a standard deviation of $17 \%$ while reducing consumption per capita by $10 \%$ giving a standard deviation of $21.40 \%$. With these relatively small changes, it can provide significant changes. The behavior of this sensitivity test is presented in Figure 4.

Sensitivity test stated that the model developed is valid and can represent real conditions for the rice availability model in West Java. Then the simulation will be carried out until 2025 according to the West Java Province Long Term Work Plan. The results of the simulation that have been carried out give the result that in 2025 the population of West Java reaches 52,841,257 people with a population growth of $1.38 \%$. Rice productivity until 2025 is 5.61 tons/ha. Or the average annual productivity is only $0.23 \%$.

GKG production is still in the range of more than 13 million tons, but there is no significant increase. The rice balance shows a significant decline at the end of 2025 . And West Java has fragile food security. For this reason, it is necessary to approach the policy evaluation and formulation of policy alternatives to avoid a reduction in the rice balance and rice deficit in West Java and to ensure the sustainable supply chain management of agricultural product competitive advantage $[33,34,35]$.

\section{Conclusions}

The results of this study found that by using actual data of the annual average growth between 2014 and 2019 amounted to $2.81 \%$ for rice production, and of $1.12 \%$ for the population, the estimated rice availability is projected until 2025. The tests and analysis that have been carried out by using Causal Loop Diagrams (CLD) and Stock and Flow Diagrams (SFD) show that productivity and availability of paddy fields are two important variables that can provide a significant influence on the rice production system as a whole. These two variables can be used as a basis for the study of policy model development in the framework of ensuring the availability of rice in West Java.

The findings demonstrated that the development of rice availability models is needed as one of the supporting tools of decision-making in developing policies to ensure the availability of rice in West Java. The findings underscore the importance of productivity and land area as the basis for the study of developing a policy model to ensure the availability of rice in West Java. Theoretically, the findings can be used as a conceptual basis for projecting sustainable rice availability in an area. The results of this study practically have implications for the need to increase productivity and governance of agriculture and rice trade as a policy basis to ensure the availability of rice in West Java.

\section{REFERENCES}

[1] Ariani M, "Dinamika Konsumsi Beras Rumah Tangga dan Kaitannya dengan Diversifikasi Konsumsi Pangan," in Kasryno, F. et al. (Eds), Ekonomi Padi dan Beras Indonesia, Jakarta: Badan Penelitian dan Pengembangan Pertanian, Departemen Pertanian, 2003.

[2] Ariyadi W., "Empirical Analysis of Farmers Household Food Security Levels in Salatiga, Indonesia," Research Horizon, vol. 1, no. 1, pp. 39-46, 2021.

[3] Baharsjah S, Kasryno F, Darmawan DH, "Kedudukan padi dalam perekonomian Indonesia," in Kasryno F. et al. (Eds), Ekonomi Padi dan Beras Indonesia, Jakarta: Badan Penlitian dan Pengembangan Pertanian, Departemen Pertanian, 1998.

[4] Timmer CP, "Does Bulog stabilise rice prices in Indonesia? Should it try?," Bulletin of Indonesian Economic Studies, vol. 32, no. 2, pp. 45-74, 1996.

[5] Mathieu JE, Tannenbaum SI, Donsbach JS, Alliger GM, “A review and integration of team composition models: Moving toward a dynamic and temporal framework," Journal of Management, vol. 40, no. 1, pp. 130-160, 2014.

[6] Rahayu S, Santoso PB, Mafruhah I, "Stakeholder role in improving agribusiness efficiency and food security in developing countries," International Journal of Economics and Business Administration, vol. 7, no. 4, pp. 464-470, 2019.

[7] Sandran K, Ibrahim NFS, Padzil SZA, Wern OK, Hudin NS, Hudin NS, Ismail RM, "Consumers' Perception of the Benefits and Challenges of Organic Food Consumption and Supply," International Journal of Supply Chain Management, vol. 9, no. 2, pp. 273, 2020.

[8] Yousuf M., "Challenges and opportunities of artificial insemination on dairy cattle in Ethiopia," Research Horizon, vol. 1, no. 2, 2021.

[9] Aprillya MR, Suryani E, Dzulkarnain A, "System Dynamics Simulation Model to Increase Paddy Production for Food Security," Journal of Information Systems Engineering and Business Intelligence, vol. 5, no. 1, pp. 67-75, 2019.

[10] Lambert DM, Pohlen TL, "Supply Chain Metrics," International Journal of Logistics Management, vol. 12, no.1, pp. 1-19, 2001.

[11] Mentzer JT, DeWitt W, Keebler JS, Min S, Nix NW, Smith $\mathrm{CD}$, Zacharia ZG, "Defining supply chain management," Journal of Business logistics, vol. 22, no. 2, pp. 1-25, 2001.

[12] New SJ, "The scope of supply chain management research," Supply Chain Management: An International Journal, vol. 2, no. 1, 1997.

[13] Nupus H., Ichwanudin W., "Business Network Accessibility, Customer Relationship Management and Shared Value Creation on Family Business Performance," Research Horizon, vol. 1, no. 4, 2021.

[14] Jamaludin M, Fauzi TH, Nugraha DNS, “A system dynamics approach for analyzing supply chain industry: Evidence from rice industry," Uncertain Supply Chain Management, vol. 9, no. 1, 2021. 
[15] Kumar S, Nigmatullin A, "A system dynamics analysis of food supply chains-Case study with non-perishable products," Simulation Modelling Practice and Theory, vol. 19, no. 10, pp. 2151-2168, 2011.

[16] Jamaludin, M, "Kelembagaan Distribusi Beras pada Perum Bulog Divisi Regional Jawa Barat," Doctoral dissertation, Universitas Padjajaran, 2015.

[17] Byerlee, D., Jayne, T. S., \& Myers, R. J, "Managing food price risks and instability in a liberalizing market environment: Overview and policy options," Food Policy, 31(4), pp. 275-287, 2006.

[18] Chuvakhina LG, Terskaya GA, Koroleva IV, Solovykh NN, Chuvakhin PI, "US and EU supply chain strategies to the food quality and security standards in Russia," International Journal of Supply Chain Management, vol. 8, no. 4, pp. 845-850, 2019

[19] Gusarova O, Yerzhanova M, Berezniak I, Konstantinov V, Vityutina T, "Supply chain management in the food industry: A comprehensive hierarchical decision-making," International Journal of Supply Chain Management, vol. 8, no. 4, pp. 733-742, 2019.

[20] Karkinbayeva SI, Kirdasinova KA, Adiyetova EM, Kanatova AZ, Korgan BB, "Topical issues surrounding supply chain management in developing food industry: Kazakhstan case study," International Journal of Supply Chain Management, vol. 8, no. 4, pp. 743-750, 2019.

[21] Ahumada O, Villalobos JR, "Application of planning models in the agri-food supply chain: A review," European journal of Operational research, vol. 196, no. 1, pp. 1-20, 2009.

[22] Georgiadis P, Vlachos D, Iakovou E, “A system dynamics modeling framework for the strategic supply chain management of food chains," Journal of food engineering, vol. 70, no. 3, pp. 351-364, 2005.

[23] Sterman JD, "Business Dynamics: Systems Thinking and Modeling for Complex World," McGraw Hill, Boston, 2002 .

[24] Chechland PB, "System Thinking, Systems Practices," Wiley Chichester, US, 1981.

[25] Manetsch RP, Park GL, "System Analysis and Simulations with Application to Economic and Social System," Michigan State University, USA, 1977.
[26] Mughal MR, "Impact of Green Supply Chain management practices on Performance of Manufacturing Companies in Jordan: A moderating role of supply chain traceability," Arthatama, vol. 3, no. 2, pp. 1-20, 2019.

[27] Indonesia Investments, Beras. 28 June 2017, Retrieved from https://www.indonesia-investments.com/id/bisnis/ko moditas/beras/item 183 .

[28] Octania G., "The Government's Role in the Indonesian Rice Supply Chain," Policy Paper No. 32, Center for Indonesian Policy Studies, 2021.

[29] Anggraeni T., "A Comparative Study of Indonesian Estimated Rice Production and Consumption," JAKPP (Jurnal Analisis Kebijakan \& Pelayanan Publik), pp. 101-112, 2020.

[30] Jamaludin M, Fauzi TH, Nugraha DNS, Adnani L, "Service supply chain management in the performance of national logistics agency in national food security," International Journal of Supply Chain Management, vol. 9, no. 3, pp. 1080-1084, 2020.

[31] Carolyn Bell, Rhonda Higgs, Stephanie Vickers, Steven Toncinich, Tim Haslett, "Using Systems Modelling to Understand the Dynamics of Supply Chains," Working Paper 70/03, December 2003, Monash University. https://doi.org/10.4225/03/5934da85b7d91.

[32] Suryani E, IJ Diajeng Permata, Hendrawan RA, Dewi LP, "Analyzing Rice Demand and Supply Behavior for Food Availability: a System Dynamics Model. Case Study: Sub-Regional Surabaya, Gresik and Sidoarjo," Information Systems International Conference (ISICO), pp. 403-408, 2013.

[33] Jamaludin M, "The influence of supply chain management on competitive advantage and company performance," Uncertain Supply Chain Management, vol. 9, no. 3, pp. 696-704, 2021.

[34] Ong'ayo AH, Ndiso JB, "Social and Cultural Factors Influencing Gender Disparity in Farmers Field Schools Approach among Smallholder Farmers in Kilifi North Sub-County, Kilifi County," Universal Journal of Agricultural Research, vol. 8, no. 5, pp. 158-164, 2020.

[35] Bil-Assanou IH, Boukari D, Sitou L, "Scaling up Assisted Natural Regeneration to Intensify Agroecologically Agrosystems Productivity," Universal Journal of Agricultural Research, vol. 8, no. 1, pp. 11-17, 2020. 